\title{
Increased expression of matrix metalloproteinases-21 and -26 and TIMP-4 in pancreatic adenocarcinoma
}

\author{
Ville Bister ${ }^{1}$, Tiina Skoog ${ }^{2,3}$, Susanna Virolainen ${ }^{4}$, Tuula Kiviluoto ${ }^{5}$, Pauli Puolakkainen ${ }^{5}$ \\ and Ulpu Saarialho-Kere ${ }^{1,2}$
}

${ }^{1}$ Department of Dermatology, Helsinki University Central Hospital and Biomedicum Helsinki, University of Helsinki, Helsinki, Finland; ${ }^{2}$ Department of Dermatology, Karolinska Institutet at Stockholm Söder Hospital, Stockholm, Sweden; ${ }^{3}$ Department of Biosciences and Nutrition, Karolinska Institutet, Novum, Huddinge, Stockholm, Sweden; ${ }^{4}$ Department of Pathology, Helsinki University Central Hospital, University of Helsinki, Helsinki, Finland and ${ }^{5}$ Department of Surgery, Helsinki University Central Hospital, University of Helsinki, Helsinki, Finland

\begin{abstract}
Pancreatic adenocarcinoma is known for early aggressive local invasion, high metastatic potential, and a low 5year survival rate. Matrix metalloproteinases (MMPs) play important roles in tumor growth and invasion. Earlier studies on pancreatic cancer have found increased expression of certain MMPs to correlate with poorer prognosis, short survival time or presence of metastases. We studied the expression of MMP-21, -26, and tissue inhibitor of matrix metalloproteinases (TIMP)-4 in 50 tissue samples, including 25 adenocarcinomas, seven other malignant pancreatic tumors, and 18 control samples of non-neoplastic pancreatic tissue with immunohistochemistry. The regulation of MMP-21, -26, and TIMP-4 mRNAs by cytokines was studied with RT-PCR in pancreatic cancer cell lines PANC-1, BxPC-3, and AsPC-1. MMP-21, -26, and TIMP-4 were detected in cancer cells in 64, 40, and $60 \%$ of tumors, respectively. MMP-21 expressed in well-differentiated cancer cells and occasional fibroblasts, like TIMP-4, tended to diminish in intensity from grade I to grade III tumors. Patients with metastatic lymph nodes had increased expression of MMP-26 in actual tumor samples. All cultured cancer cell lines expressed MMP-21 basally at low levels, and presence of the protein was confirmed immunohistochemically in cultured cells. MMP-21 expression was induced by epidermal growth factor (EGF) in PANC-1 cells. MMP-26 was neither expressed basally nor induced by tumor necrosis factor $\alpha$, transforming growth factor $\beta-1$ (TGF $\beta 1$ ), EGF, or interferon $\gamma$. Basal TIMP-4 expression was lowest in the poorly differentiated cancer cell line PANC-1 compared to better-differentiated BxPC-3 and AsPC-1 cells. TIMP-4 expression was induced by TGF $\beta 1$ in PANC-1 cells and by EGF in BxPC-3 cells. Our findings suggest that MMP-21 is not a marker of invasiveness, but rather of differentiation, in pancreatic cancer and it may be upregulated by EGF. The putative role of MMP-26 as a marker of metastases warrants further studies. Unlike other TIMPs, TIMP-4 was not upregulated in relation to aggressiveness of pancreatic cancer.

Modern Pathology (2007) 20, 1128-1140; doi:10.1038/modpathol.3800956; published online 14 September 2007
\end{abstract}

Keywords: matrix metalloproteinase; adenocarcinoma; tissue inhibitor of metalloproteinase

Pancreatic cancer is one of the most lethal types of cancer: the 5-year survival rate of pancreatic adenocarcinoma is under $5 \% .^{1,2}$ Other types of pancreatic tumors (15\% of all tumors) include insulinoma, gastrinoma, and carcinoid tumor. Pancreatic cancer is notorious for its late clinical

Correspondence: Dr U Saarialho-Kere, MD, PhD, Department of Dermatology, University of Helsinki, Meilahdentie 2, Helsinki 25, Finland.

E-mail: ulpu.saarialho-kere@helsinki.fi

Received 30 March 2007; revised 7 August 2007; accepted 9 August 2007; published online 14 September 2007 presentation, early and aggressive local invasion, and metastatic potential. ${ }^{3}$ The diagnosis is confirmed using ultrasound combined with biopsy as well as computed tomography, and tumor markers such as CA 19-9. If metastases are not found, the Whipple operation (pancreaticoduodenectomy) is performed to remove the tumor. If metastases are detected, palliative treatments are chosen, such as biliary bypass procedure or chemo/radiotherapy. A known risk factor for pancreatic cancer is smoking, which increases the risk two- to three-fold. ${ }^{4}$ Also, patients with chronic pancreatitis have increased risk for developing pancreatic carcinoma. ${ }^{5,6}$ 
Coexpression of several members of the matrix metalloproteinase (MMP) family is characteristic of human malignant tumors. ${ }^{7}$ Classical MMPs play an important role at all stages of tumorigenesis: they enhance tumor-induced angiogenesis, release growth factors from the matrix or cleave their receptors, regulate apoptosis as well as break down matrix and basement membranes to allow tumor cell invasion and metastatic spread. ${ }^{7}$ Several studies on pancreatic cancer have found that increased MMP expression correlates with poorer prognosis, short survival time, or presence of local invasion or distant metastases. ${ }^{8}$ Particularly, overexpression of MMP-7 is considered as a metastatic and prognostic marker. ${ }^{9,10}$ Furthermore, MMP-2 and -9 expression in primary tumors is associated with invasiveness and liver metastases in pancreatic carcinomas, ${ }^{11,12}$ and the degree of MMP-2 and MMP-9 overexpression has been reported to correlate with pancreatic cancer invasive potential in vitro. ${ }^{11}$ MMP inhibition by tissue inhibitor of metalloproteinases, TIMP-1, antisense gene transfection or by adenoviral delivery of TIMPs reduces the invasive potential of pancreatic cancer cells in experimental models, ${ }^{13,14}$ and synthetic MMP inhibitors may be beneficial in adjuvant treatment setting following tumor resection. ${ }^{15}$

MMP-21, which our group cloned from human placenta cDNA, ${ }^{16}$ has important functions during fetal development and in cancer biology ${ }^{17,18} \mathrm{MMP}-$ 21 is regulated at least in keratinocytes by transforming growth factor $\beta-1$ (TGF $\beta 1$ ) and is present at the invasive front of cutaneous and esophageal SCCs in epithelial cancer cells ${ }^{17,18}$ but not yet in dysplastic cells. MMP-21 can also be expressed by macrophages and fibroblasts in vivo and in vitro ${ }^{19}$ and by neutrophils in vivo. ${ }^{16,18}$ The physiological substrates of MMP-21 are still unknown: furin is its putative activator. ${ }^{16}$

MMP-26 (matrilysin-2) can degrade type IV collagen, laminin-1, fibronectin, fibrinogen, and gelatin. ${ }^{20}$ It has been found in migrating keratinocytes in normally healing skin wounds, in migrating enterocytes, macrophages, and endothelial cells, and it is suggested to be involved in cutaneous and intestinal wound repair. ${ }^{21,22}$ MMP-26 mRNA is also expressed in normal endometrial epithelium. ${ }^{23}$ MMP-26 expression is upregulated in dysplastic changes in prostatic tissue but downregulated in invasive cancer, ${ }^{24}$ and in a similar manner it becomes downregulated during histological dedifferentiation of cutaneous $\mathrm{SCCs}^{21}$ and spreading of ductal breast cancers. ${ }^{25,26}$ MMP-26 expression has also been reported in invasive esophageal, ovarian, and endometrial cancers. ${ }^{18,27,28}$

MMPs also have natural inhibitors called TIMPs. Their diminished or increased expression has been reported in various cancers depending on the tumor type. ${ }^{29,30}$ TIMP-4 was cloned from the human heart library ${ }^{31}$ and is $51 \%$ identical to TIMPs-2 and -3 . It is anti-inflammatory and can induce apoptotic cell death in transformed cells ${ }^{32}$ besides inhibiting
MMPs-1, $-2,-3,-7,-9,-14$ and MMP-26 and tumor necrosis factor $\alpha(\mathrm{TNF} \alpha)$-converting enzyme (TACE). ${ }^{33}$ TIMP-4 expression is also upregulated in dysplastic changes in prostatic tissue but downregulated in invasive cancer. $^{24}$ TIMP-4 is upregulated in cervical cancer, ovarian cancer, invasive endometrial cancer, and in ductal in situ breast cancer, and it often colocalizes with MMP-26. ${ }^{25,27,28,34}$

The aim of this study was to investigate the expression and localization of the novel MMP-21 in pancreatic cancer in vivo and in culture. More accurate tissue and serum markers could improve the early detection and prognosis of this deadly disease. As matrilysin-1 (MMP-7) has been found to be of prognostic value in pancreatic cancer, we also studied its close relative MMP-26 with its potent inhibitor TIMP-4 in this tumor type.

\section{Materials and methods}

\section{Subjects and Tissue}

The study involved surgical specimens from 35 consecutive patients undergoing surgery for malignant pancreatic tumors at Helsinki University Central Hospital between March 1999 and December 2004 (Table 1). Formalin-fixed, paraffin-embedded routine archival specimens of pancreatic adenocarcinoma $(n=25)$, mucinous carcinoma $(n=3)$, cystadenocarcinoma $(n=2)$, malignant insulinoma $(n=2)$, and benign pancreatic tumors $(n=4)$ from 35 patients (18 male and 17 female subjects, mean age 62 years, range 21-75 years) (Table 1) were obtained during Whipple operations at the Department of Surgery. Of the 25 adenocarcinoma samples studied, three were well differentiated (grade I), 18 were moderately differentiated (grade II), and four were poorly differentiated (grade III) (Table 1). Additionally, 18 specimens representing the healthy margins of pancreatic tumors taken from the same patients were studied (Table 1). Histological grade was evaluated by two independent pathologists (Table 1). Staging was carried out according to UICC 1997 TNM classification, on the basis of patient records, imaging methods, operation records, and histological evaluation. Median survival for patients who had adenocarcinoma was 29 months. The study was approved by the corresponding Ethical Committee and followed the Declaration of Helsinki Guidelines.

\section{Immunohistochemistry}

Immunohistochemistry was performed using streptavidin-biotin-peroxidase complex technique (DakoCytomation, StreptABComplex/HRP Duet, Mouse/Rabbit, Glostrup, Denmark). Diaminobenzidine (DAB) or 3-amino-9-ethylcarbazole (AEC) (cells 
Table 1 Clinical parameters of patients with pancreatic tumors

\begin{tabular}{|c|c|c|c|c|c|c|}
\hline Patient & Sex/age & $D g$ & $T N M$ & Grade & $\begin{array}{l}\text { Survival } \\
\text { (months) }\end{array}$ & CA $19-9$ \\
\hline $1^{\mathrm{a}}$ & $\mathrm{M} / 64$ & Adenocarcinoma & T1N1M0 & Well differentiated & 24 & 25 \\
\hline 2 & $\mathrm{M} / 75$ & Adenocarcinoma & T3N1M1 & Moderately differentiated & 35 & 485 \\
\hline 3 & $\mathrm{M} / 73$ & Adenocarcinoma & T3N1M0 & Poorly differentiated & 8 & 196 \\
\hline $4^{\mathrm{a}}$ & $\mathrm{F} / 66$ & Adenocarcinoma & T3N0M0 & Moderately differentiated & 11 & 20 \\
\hline $5^{\mathrm{a}}$ & $\mathrm{F} / 64$ & Adenocarcinoma & T3N0M0 & Moderately differentiated & 17 & 444 \\
\hline $6^{\mathrm{a}}$ & $\mathrm{F} / 56$ & Adenocarcinoma & T3N1M0 & Moderately differentiated & 14 & 497 \\
\hline 7 & $\mathrm{M} / 66$ & Adenocarcinoma & T3N1M0 & Poorly differentiated & 39 & 3870 \\
\hline 8 & $\mathrm{~F} / 61$ & Adenocarcinoma & T1N0M0 & Moderately differentiated & 36 & ND \\
\hline $9^{\mathrm{a}}$ & $\mathrm{M} / 55$ & Adenocarcinoma & T3N1M0 & Well differentiated & 18 & 2144 \\
\hline $10^{\mathrm{a}}$ & $\mathrm{M} / 62$ & Adenocarcinoma & T3N1M0 & Moderately differentiated & 35 & 855 \\
\hline $11^{\mathrm{a}}$ & $\mathrm{M} / 63$ & Adenocarcinoma & T2N1M0 & Moderately differentiated & 35 & $<5$ \\
\hline $12^{\mathrm{a}}$ & $\mathrm{F} / 73$ & Adenocarcinoma & T4N0M0 & Moderately differentiated & 6 & 356 \\
\hline $13^{\mathrm{a}}$ & $\mathrm{M} / 61$ & Adenocarcinoma & T4N1M0 & Moderately differentiated & 3 & 183 \\
\hline 14 & $\mathrm{M} / 61$ & Adenocarcinoma & T3N1M0 & Moderately differentiated & 31 & 20 \\
\hline 15 & $\mathrm{~F} / 56$ & Adenocarcinoma & T3N0M0 & Moderately differentiated & 17 & 228 \\
\hline 16 & $\mathrm{M} / 67$ & Adenocarcinoma & T3N0M0 & Moderately differentiated & 48 & 564 \\
\hline 17 & $\mathrm{M} / 59$ & Adenocarcinoma & T2N1M0 & Poorly differentiated & 18 & ND \\
\hline $18^{\mathrm{a}}$ & $\mathrm{F} / 64$ & Adenocarcinoma & T3N0M0 & Moderately differentiated & 13 & 387 \\
\hline 19 & $\mathrm{M} / 63$ & Adenocarcinoma & T3N1M0 & Poorly differentiated & 43 & 46 \\
\hline $20^{\mathrm{a}}$ & $\mathrm{F} / 66$ & Adenocarcinoma & T2N0M0 & Moderately differentiated & 29 & 2183 \\
\hline 21 & $\mathrm{M} / 72$ & Adenocarcinoma & T3N1M0 & Moderately differentiated & 3 & $<5$ \\
\hline 22 & $\mathrm{M} / 54$ & Adenocarcinoma & T3N0M0 & Moderately differentiated & 81 & 1139 \\
\hline $23^{\mathrm{a}}$ & $\mathrm{M} / 75$ & Adenocarcinoma & T4N0M0 & Moderately differentiated & 7 & 758 \\
\hline $24^{\mathrm{a}}$ & $\mathrm{F} / 69$ & Adenocarcinoma & T4N1M0 & Well differentiated & 75 & 123 \\
\hline 25 & $\mathrm{M} / 60$ & Adenocarcinoma & T2NoMo & Moderately differentiated & 86 & 59 \\
\hline 26 & $\mathrm{~F} / 64$ & Mucinous adenocarcinoma & T4N1M0 & Well differentiated & 19 & 113 \\
\hline $27^{\mathrm{a}}$ & $\mathrm{F} / 53$ & Cystadenocarcinoma & T2NoMo & Cystadenocarcinoma mucinosum & 45 & ND \\
\hline $28^{\mathrm{a}}$ & $\mathrm{F} / 44$ & Mucinous cystadenocarcinoma & T2NoMo & Caput: cystadenocarcinoma mucinosum & 45 & ND \\
\hline $28^{\mathrm{a}}$ & $\mathrm{F} / 44$ & Papillary mucinous carcinoma & T2NoMo & Cauda: ca mucinosum papilla intraductale & 45 & ND \\
\hline 29 & $\mathrm{~F} / 69$ & Mucinous cystadenocarcinoma & T4N0M0 & Dysplasia levis, invasive & 71 & 3500 \\
\hline 30 & $\mathrm{~F} / 54$ & Malignant insulinoma & T3N1M0 & WHO r 2, well differentiated & 37 & $<5$ \\
\hline 31 & $\mathrm{M} / 69$ & Malignant insulinoma & T2N0M0 & WHO r 2, well differentiated & 82 & 20 \\
\hline $32^{\mathrm{a}}$ & $\mathrm{F} / 69$ & Mb Castleman & - & Typus hyalin-vascular & 26 & 16 \\
\hline 33 & $\mathrm{M} / 46$ & Benign insulinoma & - & Proliferation activity $<1 \%$, noninvasive & 26 & ND \\
\hline $34^{\mathrm{a}}$ & $\mathrm{F} / 21$ & Pseudopapillary tumor & T2NoMo & Neoplasma solidum pseudopapillare & 50 & $<5$ \\
\hline 35 & $\mathrm{~F} / 64$ & Serous cystadenoma & T3N0M0 & Cystadenoma serosum typus microcysticus & 43 & 9 \\
\hline
\end{tabular}

${ }^{\mathrm{a} C o n t r o l ~ s a m p l e ~ a v a i l a b l e . ~}$

cultured on chamber slides) was used as chromogenic substrate, and sections were counterstained with Mayer's hematoxylin. Samples were immunostained using polyclonal antibodies to MMP-26 $(1: 150),{ }^{21}$ MMP-21 (1:150), ${ }^{17}$ TIMP-4 (1:700) (Neomarkers, RB-1542-P), and $\gamma-2$ chain of laminin-5 (1:700, a gift from Professor Karl Tryggvason, Karolinska Institute, Sweden) ${ }^{35}$ as well as by using monoclonal antibodies to MMP-7 (IM40L, 1:100, Calbiochem). MMP-21 and laminin-5 stainings required pre-treatment with $10 \mathrm{mg} / \mathrm{ml}$ trypsin, and MMP-7, -26, and TIMP-4 pre-treatment in $+95^{\circ} \mathrm{C}$ water bath for $30 \mathrm{~min}$ in DakoCytomation citratebuffer. MMP-7, -21, TIMP-4, and laminin-5 antibodies were incubated at $+4^{\circ} \mathrm{C}$ overnight and MMP-26 at $+37^{\circ} \mathrm{C}$ for $1 \mathrm{~h}$. For negative controls, we used preimmune sera or normal rabbit/mouse immunoglobulin. Results on TIMP-4 were also confirmed on both tissues and Lab-Tek cultures using another antibody (Ab2170, Abcam, Cambridge, UK).

Immunohistochemical specimens were graded semiquantitatively by two independent investiga- tors (VB, US-K) under a light-field microscope at $\times 100$ magnification counting the median of four fields using a scale marking staining intensity as follows: $0=$ under 10 positive cells; $1=10-20$ positive cells; $2=20-50$ positive cells; $3=$ over 50 positive cells. The overall intensity of staining was calculated as mean values from intensity numbers 0 , 1,2 , and 3 , respectively (Table 2). Histological confirmation and precise cell recognition were made by the pathologist (SV).

\section{Chemicals and Materials}

Cell culture media and fetal bovine serum (FBS) were from Cambrex (East Rutherford, NJ, USA), cytokines and chemicals from Sigma (St Louis, MO, USA). Cell culture plastic ware was from Falcon, BectonDickinson (Franklin Lakes, NJ, USA), and Lab-Tek chamber slides from Nunc (Naperville, IL, USA). Reagents for real-time quantitative PCR were purchased from Applied Biosystems (Warrington, UK). 
Table 2 Correlation of MMP-21, MMP-26, and TIMP-4 expression with clinical and histological parameters in pancreatic adenocarcinomas

\begin{tabular}{|c|c|c|c|c|c|c|c|c|c|c|c|}
\hline \multirow[t]{2}{*}{ Intensity of staining } & \multirow[t]{2}{*}{ Cases } & \multicolumn{3}{|c|}{$M M P-21$} & \multicolumn{3}{|c|}{$M M P-26$} & \multicolumn{4}{|c|}{ TIMP-4 } \\
\hline & & 0 & 1 & 2 & 0 & 1 & 2 & 0 & 1 & 2 & 3 \\
\hline Well differentiated & 3 & 1 & 2 & 0 & 0 & 2 & 1 & 1 & 1 & 1 & 0 \\
\hline Moderately differentiated & 18 & 2 & 10 & 6 & 11 & 4 & 3 & 2 & 10 & 5 & 1 \\
\hline Poorly differentiated & 4 & 0 & 2 & 2 & 1 & 2 & 1 & 0 & 1 & 3 & 0 \\
\hline $\mathrm{T} 1$ & 2 & 0 & 1 & 1 & 0 & 2 & 0 & 1 & 0 & 0 & 1 \\
\hline T2 & 4 & 0 & 2 & 2 & 3 & 0 & 1 & 0 & 1 & 3 & 0 \\
\hline T3 & 15 & 1 & 9 & 5 & 7 & 5 & 3 & 2 & 7 & 6 & 0 \\
\hline $\mathrm{T} 4$ & 4 & 2 & 2 & 0 & 2 & 1 & 1 & 0 & 4 & 0 & 0 \\
\hline No & 11 & 1 & 7 & 3 & 8 & 3 & 0 & 2 & 5 & 3 & 1 \\
\hline N1 & 14 & 2 & 7 & 5 & 4 & 5 & 5 & 1 & 7 & 6 & 0 \\
\hline M0 & 24 & 3 & 14 & 7 & 11 & 8 & 5 & 3 & 11 & 9 & 1 \\
\hline M1 & 1 & 0 & 0 & 1 & 1 & 0 & 0 & 0 & 1 & 0 & 0 \\
\hline Over 5 years survival & 3 & 0 & 2 & 1 & 1 & 1 & 1 & 0 & 1 & 2 & 0 \\
\hline 1-5 years survival & 16 & 1 & 9 & 6 & 7 & 5 & 4 & 3 & 6 & 6 & 1 \\
\hline Under 1 year survival & 6 & 2 & 3 & 1 & 4 & 2 & 0 & 0 & 5 & 1 & 0 \\
\hline Normal CA19-9 (<37) & 5 & 0 & 3 & 2 & 2 & 1 & 2 & 1 & 3 & 1 & 0 \\
\hline Elevated CA19-9 (38-200) & 5 & 1 & 2 & 2 & 1 & 2 & 2 & 0 & 2 & 3 & 0 \\
\hline Strongly elevated CA19-9 (>200) & 13 & 2 & 8 & 3 & 8 & 4 & 1 & 2 & 7 & 4 & 0 \\
\hline Altogether & 25 & 3 & 14 & 8 & 12 & 8 & 5 & 3 & 12 & 9 & 1 \\
\hline Controls & 18 & 14 & 4 & 0 & 16 & 2 & 0 & 11 & 4 & 3 & 0 \\
\hline
\end{tabular}

\section{Cell Culture Models}

The expression of MMP-21, MMP-26, and TIMP-4 genes was studied in three pancreatic carcinoma cell lines: PANC-1 (poorly differentiated carcinoma cells) $^{36}$ (ATCC, CRL-1469), BxPC-3 (moderately well- to poorly differentiated carcinoma cells ${ }^{37}$ (ATCC, CRL-1687), and AsPC-1 (well to poorly differentiated carcinoma cells) ${ }^{38}$ (ATCC, CRL-1682). PANC-1 cells were cultured in Dulbecco's modified Eagle's medium (DMEM) supplemented with 10\% FBS, $2 \mathrm{mM}$ of L-glutamine, $100 \mathrm{U}$ of penicillin, and $100 \mu \mathrm{g} / \mathrm{ml}$ streptomycin. BxPC-3 and AsPC-1 cells were cultured in RPMI 1640 medium supplemented with $10 \%$ FBS, $2 \mathrm{mM}$ of L-glutamine, $100 \mathrm{U}$ of penicillin, and $100 \mu \mathrm{g} / \mathrm{ml}$ streptomycin. The medium was changed three times a week. Cells were seeded as they reached confluence. After trypsinization, cells were subcultivated at a ratio of 1:2-1:4. To study the regulation of MMP-21, MMP-26, and TIMP-4 expression, cells were plated on six-well plates and grown overnight. Then, the cells were depleted of serum overnight before stimulation with $\mathrm{TNF} \alpha(10$ and $50 \mathrm{ng} / \mathrm{ml})$, TGF $\beta 1$ (5 and $20 \mathrm{ng} / \mathrm{ml}$ ), interferon $\gamma$ (IFN $\gamma$ : 10 and $25 \mathrm{ng} / \mathrm{ml}$ ), and epidermal growth factor (EGF: 10 and $20 \mathrm{ng} / \mathrm{ml}$ ). Stimulation was allowed to proceed for $24 \mathrm{~h}$, after which the cells were lysed and total RNA was extracted using RNeasy Mini-kit (Qiagen) as instructed by the manufacturer. Cells given fresh serum-free medium were used as controls. All treatments were carried out in triplicate, and the results were confirmed in at least two independent experiments on all three cell lines. All cells were also grown on Lab-Tek chamber slides without cytokines and fixed with formalin for immunostaining. ${ }^{21}$

\section{Conventional PCR}

Primers and probes for MMP-21 and MMP-26 were as previously described. ${ }^{17,21}$ Commercial TIMP-4 (Applied Biosystems: primer set Hs00162784_m1) and glyceraldehyde-3-phosphate dehydrogenase (GAPDH) (Applied Biosystems, VIC-TAMRA, Art. No. 4310884 E) assays were used. PCR analyses were performed using the complementary DNAs (cDNAs) reverse-transcribed for real-time PCR analyses. Placenta poly(A) (Ambion, Austin, TX, USA) was used as a positive control for MMP-21, MMP-26, and TIMP-4 expression. PCR assays were performed in $25 \mu \mathrm{l}$ volumes using $3 \mu \mathrm{l}$ of cDNA for MMP-21 and TIMP-4/GAPDH and $5 \mu \mathrm{l}$ of cDNA for MMP-26/ GAPDH, $200 \mathrm{nM}$ of each primer (T21F, T21R, T26F, T26R) and $1.25 \mu \mathrm{l}$ of TIMP-4 assay and GAPDH assay, $1 \times$ reaction buffer for DNA polymerase, $200 \mu \mathrm{M}$ of each nucleotide, and $0.75 \mathrm{U}$ of Ampli Taq Gold ${ }^{\mathrm{TM}}$ polymerase (Applied Biosystems). The PCR was started with $2 \mathrm{~min}$ at $50^{\circ} \mathrm{C}$ and an initial 10 min denaturation at $95^{\circ} \mathrm{C}$, followed by a total of 30 cycles (MMP-21 and TIMP-4), 40 cycles (MMP$26)$, or 25 cycles (GAPDH) of $15 \mathrm{~s}$ denaturation at $95^{\circ} \mathrm{C}$, and $1 \mathrm{~min}$ of annealing and elongation at $60^{\circ} \mathrm{C}$. MMP-21, MMP-26, TIMP-4, and GAPDH reactions were carried out in separate tubes. The reaction products were run in a $2 \%$ agarose gel, stained with $5 \mathrm{ng} / \mathrm{ml}$ ethidium bromide, and visualized under ultraviolet light.

\section{Quantitative Real-Time PCR (TaqMan RT-PCR)}

Half a microgram of total cellular RNA from cultured cells was reverse transcribed to cDNA with 

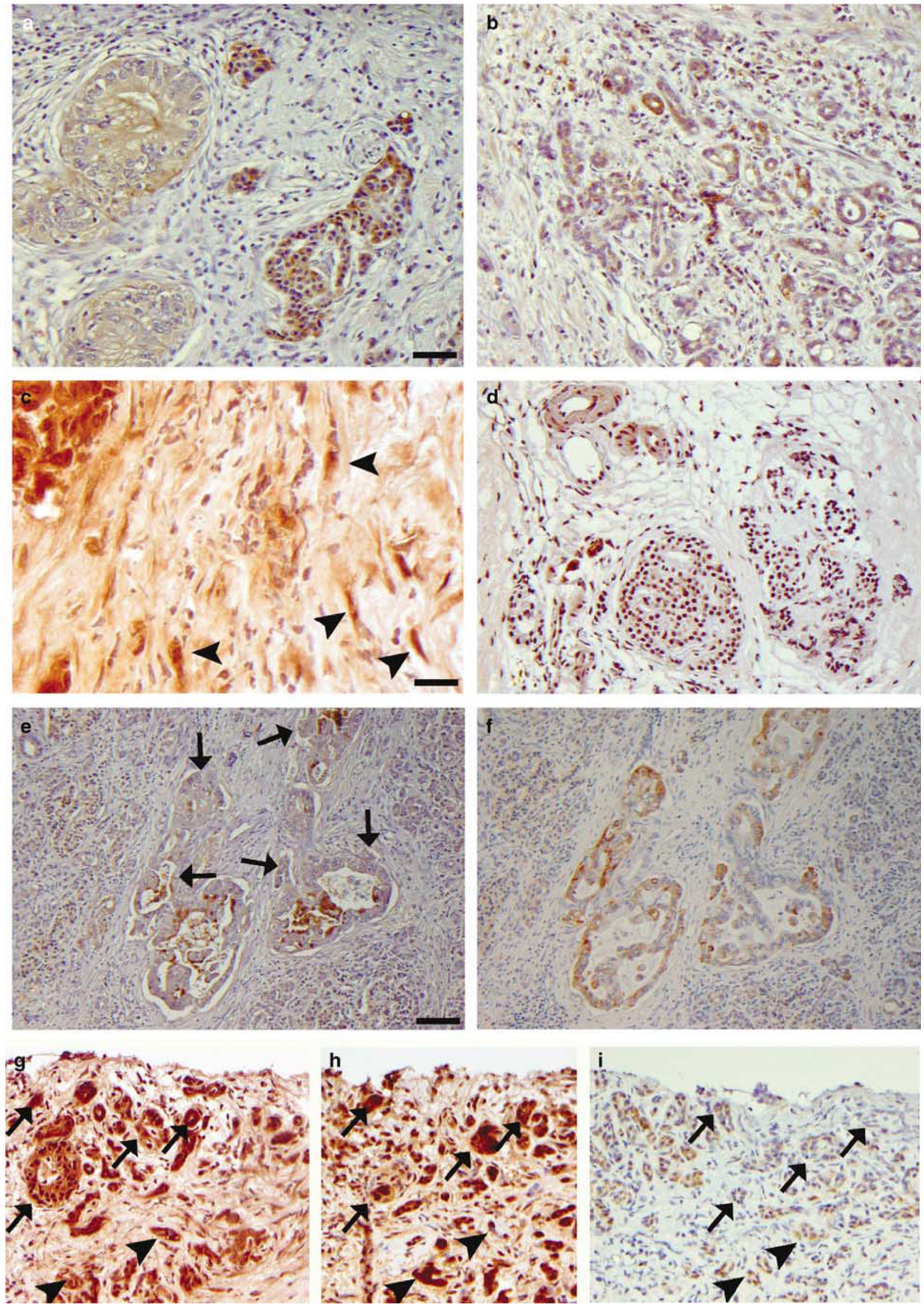
SuperScript $^{\mathrm{TM}}$ III First-Strand Synthesis System for RT-PCR (Invitrogen, Carlsbad, CA, USA) with oligo $\mathrm{dTs}$ and used as a template for TaqMan ${ }^{\mathrm{TM}}$ real-time quantitative PCR. Reactions were performed with Applied Biosystems 7500 Real-Time PCR System (Applied Biosystems). PCR amplifications were performed in $10 \mu \mathrm{l}$ volumes, MMP-21, -26 or TIMP4 and GAPDH in separate reactions. The mix contained $200 \mathrm{nM}$ primers and $100 \mathrm{nM}$ probe for MMP-21 and MMP-26 or $0.5 \mu$ l of the $20 \times$ ready-touse primer and probe mix for GAPDH and TIMP-4, $2 \mu \mathrm{l}$ of the undiluted cDNA, and $1 \times$ TaqMan $^{\mathrm{TM}}$ Universal Master Mix. The PCR was started for $2 \mathrm{~min}$ at $50^{\circ} \mathrm{C}$ and an initial $10 \mathrm{~min}$ denaturation at $95^{\circ} \mathrm{C}$, followed by a total of 40 cycles of $15 \mathrm{~s}$ denaturation at $95^{\circ} \mathrm{C}$, and $1 \mathrm{~min}$ of annealing and elongation at $60^{\circ} \mathrm{C}$. Human GAPDH labeled with VIC $^{\mathrm{TM}}$ reporter dye (Pre-developed TaqMan ${ }^{\mathrm{TM}}$ assay reagents for endogenous control human GAPDH, Applied Biosystems) was used as an endogenous control in quantitative real-time polymerase chain reaction $\left(\mathrm{TaqMan}^{\mathrm{TM}}\right)$. As a positive control for the expression of MMP-21, -26, and TIMP-4 mRNA in conventional RT-PCR and TaqMan analyses, we used placental mRNA as previously described. ${ }^{17,21}$

\section{Statistics}

The Student's unpaired $t$-test was performed in comparing mean values counted based on semiquantitative grading of immunohistochemistry slides (see above), and $P<0.05$ was accepted as a significant result. Statistical significance of the differences in mRNA expression levels in TaqMan analyses was calculated using a two-sample Student's $t$-test.

\section{Results}

\section{Expression of MMP-21 in Pancreatic Cancer}

Expression of MMP-21 protein was detected in $22 / 25$ adenocarcinoma samples and in 4/18 control samples. Staining was more intense in tumor samples (1.2 vs 0.22, $P<0.0000005)$ (Table 2). In adenocarcinomas, positivity was observed in actual carcinoma cells in 16/25 tumors (Figure 1a). In grade III tumors, 1/4 samples showed positivity in moderately differentiated cancer cells (Table 2) but not in poorly differentiated ones. In samples that had moderately and poorly differentiated cancer cells, only moderately differentiated cells showed positivity in 13/18 grade II samples (Figure 1a). In grade I samples, cancer cells were positive in $2 / 3$ samples (Table 2). MMP-21 concentrated in the central regions of the tumors and was not prominent at the invasive front (Figure 1b). In cancer samples, the surrounding normal ductal structures were immunopositive in $6 / 25$ samples. Of the samples, $3 / 25$ showed positivity for MMP-21 in fibroblasts (Figure 1c). In immunopositive cancer cells, MMP-21 partly colocalized with MMP-7 (Figure 1g and h) while MMP-26 did not colocalize with MMP-21 (data not shown). Nineteen samples adjacent to those stained for MMP-21 were immunostained for laminin-5, a good indicator of migratory cancer cells. ${ }^{35}$ Although MMP-21 was often expressed by cancer cells in the same regions as laminin-5, they did not generally colocalize in the same cells (Figure 1e and f). In control samples, immunopositive structures were normal ducti and occasional macrophages (Figure 1d). MMP-21 expression diminished from T2 toward T4 (T2 1.5 vs T4 0.5, $P<0.05$ ) (Table 2). MMP-21 expression neither associated with the presence of metastatic lymph nodes nor with alterations in CA19-9 values (Table 2). The overall intensities of MMP-21, -26, or TIMP-4 stainings did not show statistically significant correlations with different categories of survival time (Table 2). In mucinous adenocarcinomas and cystadenocarcinomas, MMP-21 was detected in cancer cells while malignant insulinomas were negative.

\section{Expression of MMP-26 in Pancreatic Cancer}

Expression of MMP-26 protein was detected in $13 / 25$ adenocarcinoma samples and in 2/18 control samples, and staining was more intense in tumor samples $(0.72$ vs $0.11, P<0.001)$ (Table 2$)$.

In adenocarcinomas, positivity was observed in actual carcinoma cells in 10/25 samples (Figure 2a). In grade III cancer, 2/4 samples showed positivity, which was found in moderately differentiated cells but not in poorly differentiated cells (Figure 2a). In grade II tumors, immunostaining was positive in 5/18 samples. All grade I cancer samples were immunopositive. In cancer samples, the surrounding normal ducti and blood vessel walls were immunopositive in 12/25 samples (Figure 2b). Elastic fibers surrounding blood vessels were positive in $4 / 25$ samples (data not shown). There were some inflammatory cells in almost all of the tumor samples, but only $4 / 25$ samples showed positivity for MMP-26 in fibroblast/macrophage-like cells (data not shown). In immunopositive cancer cells,

Figure 1 (a) MMP-21 is expressed by cancer cells in a grade II pancreatic adenocarcinoma and the staining diminishes in poorly differentiated cells. (b) MMP-21 immunopositivity concentrated in the central regions of the tumors and not at the invasive front. (c) Occasional fibroblasts (arrowheads) surrounding the tumor were also immmunopositive. (d) In control samples, MMP-21 stained occasional ducti. (e) MMP-21 immunopositivity was found in the same regions but not in the same cells as laminin-5 (f). Arrows in (e) mark MMP-21-negative areas, which are strongly positive for laminin-5. (g) MMP-21 partially colocalized in the same regions as (h) MMP-7 and (i) TIMP-4. Arrows and arrowheads depict corresponding spots. Scale bars: $12.5 \mu \mathrm{m}$ (c), $25 \mu \mathrm{m}(\mathbf{a}, \mathbf{b}, \mathbf{d}, \mathbf{g}-\mathbf{i}), 50 \mu \mathrm{m}(\mathbf{e}, \mathbf{f})$. 

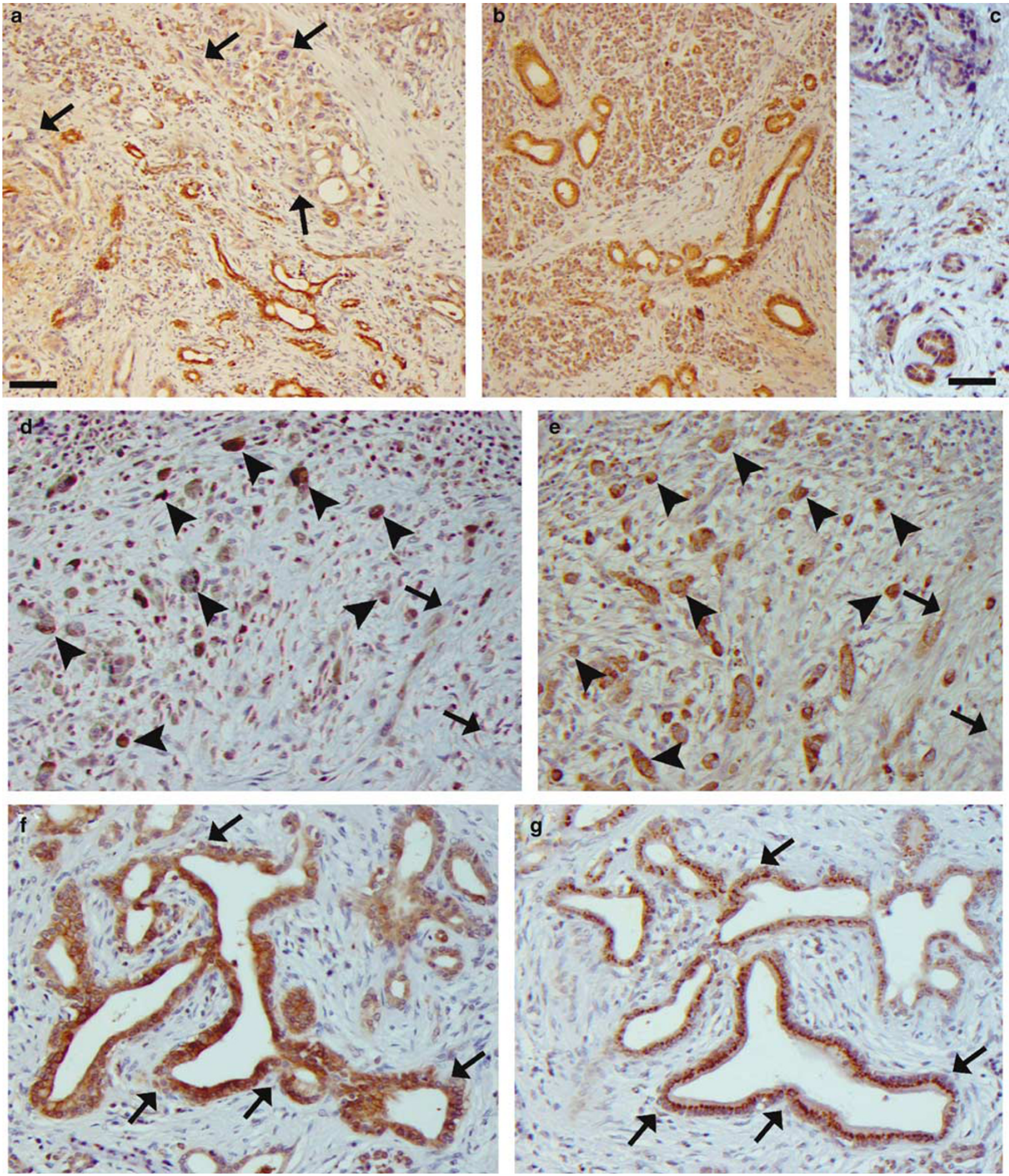

Figure 2 (a) MMP-26 expression in cancer cells in a grade II pancreatic adenocarcinoma and the staining diminishes in poorly differentiated cancer cells (arrows). (b) In a grade II cancer, large benign ductal structures were immunopositive for MMP-26. (c) In control samples, MMP-26 stained occasional ductal structures. (d) In adjacent sections, MMP-26 partly colocalized with (e) laminin-5. Arrowheads depict cells positive for both MMP-26 and laminin-5 and arrows corresponding spots. (f) In cancer samples, MMP-26 colocalized with (g) TIMP-4. Arrows depict corresponding spots in (f) and (g). Scale bars: $25 \mu \mathrm{m}$ (c-g), $50 \mu \mathrm{m}(\mathbf{a}, \mathbf{b})$.

MMP-26 colocalized with TIMP-4 (Figure 2f and g). In control samples, immunopositive structures were normal ducti (Figure 2c). Control samples were less immunostained than moderately differentiated adenocarcinoma samples (0.11 vs 0.56, $P<0.04)$. MMP-26 expression tended to increase from $\mathrm{T} 2$ to $\mathrm{T} 4$ (T2 

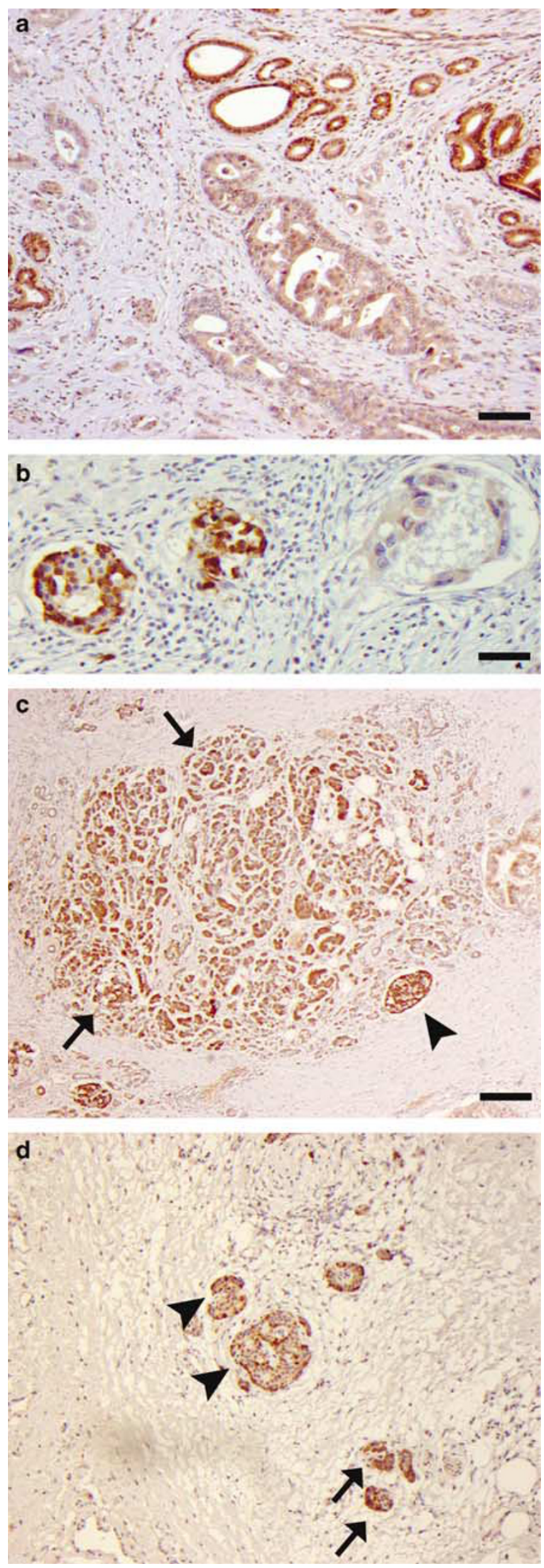

$0.5 \pm 1.0$, T3 $0.73 \pm 0.80, \mathrm{~T} 40.75 \pm 0.96$ ) (Table 2), but this did not reach statistical significance. However, MMP-26 was significantly more often expressed in tumors having metastatic lymph nodes (No $0.27 \mathrm{vs}$ N1 1.07, $P<0.006$ ) (Table 2). Actual cancer cells in primary tumors were immunopositive for MMP-26 in 10/14 lymph-node-positive patients, and none of the 11 patients negative for lymph node metastasis demonstrated MMP-26 immunopositivity. Unlike MMP-21, MMP-26 colocalized with laminin-5-positive cancer cells in $50 \%(5 / 10)$ of cancer samples (Figure $2 \mathrm{~d}$ and e). No correlation of MMP-26 expression with CA 19-9 values was noted (Table 1). In mucinous adenocarcinomas and cystadenocarcinomas, MMP-26 was detected in cancer cells while malignant insulinomas were negative.

\section{Expression of TIMP-4 in Pancreatic Cancer}

Expression of TIMP-4 protein was detected in 22/25 adenocarcinoma samples and in 7/18 control samples, and staining was more intense in tumor samples (1.32 vs $0.56, P<0.003)$ (Table 2). In adenocarcinomas, positivity was observed in actual carcinoma cells in 15/25 samples (Figure 3a). In grade III cancer, $3 / 4$ samples showed positivity in cancer cells, which was found in moderately differentiated but not in poorly differentiated cells (Figure 3a and b). In grade II samples, immunostaining was positive in $10 / 18$ samples. In grade I cancers, TIMP-4-positive cells were detected in $2 / 3$ samples. When cellular atypia arose, TIMP-4 immunostaining decreased. However, overall expression increases with TIMP-4 when cells become more undifferentiated (controls 0.56 vs intermediately differentiated 1.28, $P<0.008$ and poorly differentiated 1.75, $P<0.007)$. TIMP-4 was also found at the edges of the tumor islands but not at the invasive front. In cancer samples, the surrounding normal ducti and the islets of Langerhans were immunopositive in 10/25 samples (Figure 3c). TIMP-4 was not detected in inflammatory cells or endothelial cells, but immunopositive fibroblasts were seen in 4/25 samples (data not shown). In immunopositive cancer cells, TIMP-4 partially colocalized with MMP-7 and MMP-26 (Figures 1h, i and 2f, g). In control samples, immunopositive structures were normal ducti and islets of Langerhans (Figure 3d). In several samples, controls (5/18) and carcinomas (4/25), the islets of Langerhans showed a positive immunosignal. TIMP-4 expression tended to diminish from T2 to T4 (T1 $1.5 \pm 2.12$, T2 $1.75 \pm 0.5$, T3

Figure 3 (a) TIMP-4-positive cancer cells in a grade II pancreatic adenocarcinoma sample. (b) TIMP-4 staining diminished in poorly differentiated cancer cells. (c) In cancer samples, benign ductal structures (arrow) and islets of Langerhans (arrowhead) were immunopositive for TIMP-4. (d) Immunopositive islets of Langerhans (arrowheads) and benign ductal structures (arrows) in a control sample. Scale bars: $25 \mu \mathrm{m}$ (b), $50 \mu \mathrm{m}$ (a, d), $100 \mu \mathrm{m}$ (c). 
$1.27 \pm 0.70$, T4 $1.00 \pm 0.00$ ), but this did not reach statistical significance. TIMP-4 expression correlated with increased CA19-9 values: (mean values 325-581-830, corresponding to immunograding 0-1-2) (Table 2). TIMP-4 was not expressed by malignant cells in mucinous adenocarcinomas, cystadenocarcinomas, or insulinomas.

As a positive control, expression of MMP-7 protein was studied. It was detected in 9/9 studied adenocarcinoma samples in cancer cells (Figure 1h). Macrophages were immunopositive in 5/9 adenocarcinoma samples (data not shown).

Expression of MMP-21, MMP-26, and TIMP-4 mRNAs in Pancreatic Carcinoma Cell Lines and Regulation by Cytokines

MMP-21 was expressed basally at low levels in PANC-1 (34 cycles), BxPC-3 (34 cycles), and AsPC-1 (34 cycles) (Figure 4b). MMP-21 expression was induced 1.8-fold by EGF ( $10 \mathrm{ng} / \mathrm{ml})$ in PANC-1 cells (Figure 4a). In AsPC-1 cells, TNF $\alpha$ (10 and $50 \mathrm{ng} / \mathrm{ml}$ ) and TGF $\beta 1$ (5 and $20 \mathrm{ng} / \mathrm{ml}$ ) consistently downregulated the expression of MMP-21 0.6-fold and 0.7-fold, respectively (Figure 4a and b). In the BxPC-3 cell line, cytokines did not influence MMP-21 levels. When cells cultured on chamber slides were stained for MMP-21, the protein was detected in the cytoplasm of PANC-1, BxPC-3, and AsPC-1 cells (Figure 5a, c and d).

MMP-26 was not produced basally in any of the three pancreatic cancer cell lines, and none of the tested cytokines consistently upregulated MMP-26 mRNA in them.

TIMP-4 was expressed basally in PANC-1 (35 cycles), BxPC-3 (29 cycles), and AsPC-1 (25 cycles) cells (Figure 4c). TIMP-4 expression was induced 2.7-fold by EGF $(10 \mathrm{ng} / \mathrm{ml})$ in BxPC-3 cells, and 2.9fold by TGF $\beta 1(20 \mathrm{ng} / \mathrm{ml})$ in PANC-1 cells (Figure 4c and d). In AsPC-1 cells, IFN $\gamma$ (10 and $25 \mathrm{ng} / \mathrm{ml}$ ) consistently downregulated the expression of TIMP-4 (Figure 4c and d). When cells cultured on chamber slides were stained for TIMP-4, the protein was detected in PANC-1 and AsPC-1 cells (Figure 5e and f).

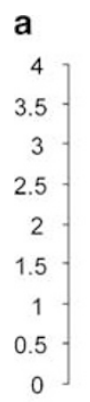

Relative expression of MMP-21 mRNA

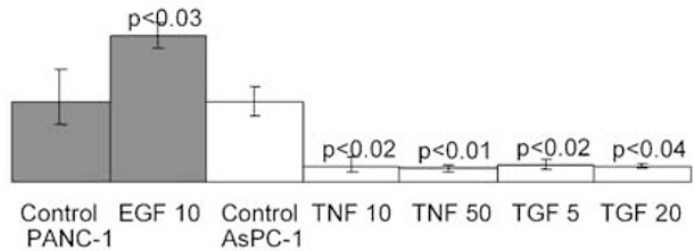

b

PANC-1 PANC-1 AsPC-1 AsPC-1 AsPC-1 Control EGF 10 Control TNF 50 TGF 20

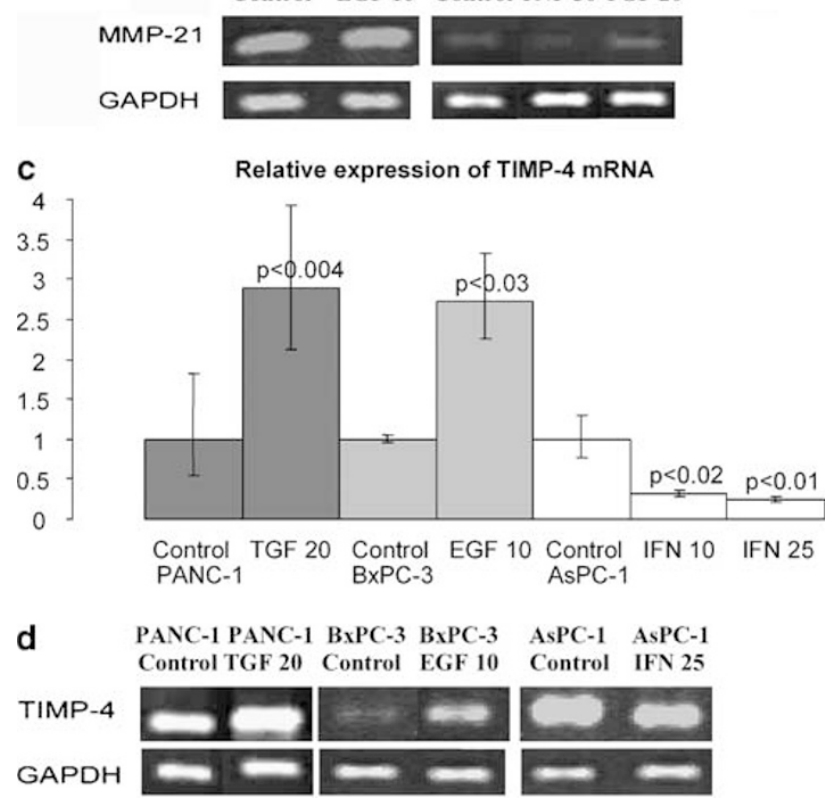

Figure 4 (a) Expression of MMP-21 mRNA in cultured PANC-1 and AsPC-1 cell lines as assessed by quantitative PCR. The results are shown relative to mRNA levels from the corresponding control cells, assigned the value 1 . One representative of three experiments in total of each cell type is shown in the figure. The vertical lanes represent range values. (b) Expression of MMP-21 (upper lane) and GAPDH (lower lane) in PANC-1 and AsPC-1 cell lines by RT-PCR. (c) Expression of TIMP-4 mRNA in cultured PANC-1, BxPC-3, and AsPC-1 cell lines as assessed by quantitative PCR. (d) Expression of TIMP-4 (upper lane) and GAPDH (lower lane) in PANC-1, BxPC-3, and AsPC-1 cell lines by RT-PCR.

\section{Discussion}

The process of epithelial cancer cell metastasis consists of a series of linked sequential events and MMPs, capable of degrading basement membranes, are believed to be crucial players. MMP gene expression is transcriptionally regulated by various

growth factors, cytokines, extracellular matrix components, and cell-cell contacts. ${ }^{7}$ This is the first report investigating MMP-21 and MMP-26 as well as its inhibitor TIMP-4 in pancreatic cancer. We found MMP-21 in cancer cells of well- and moderately

Figure 5 Expression of MMP-21 and TIMP-4 protein in cultured cells. (a) Cytoplasmic staining for MMP-21 in PANC-1 cell line. (b) Negative control for PANC-1 cells carried out with rabbit preimmune serum. (c) Cytoplasmic staining for MMP-21 in BxPC-3 cell line. (d) Cytoplasmic staining for MMP-21 in AsPC-1 cell line. (e) Cytoplasmic staining for TIMP-4 in PANC-1 cells. (f) TIMP-4 protein can also be detected in AsPC-1 cells. (g) Negative immunocontrol for AsPC-1 cells was carried out with normal rabbit immunoglobulin. Aminoethylcarbazole was used as chromogenic substrate and counterstaining was performed with hematoxylin. Original magnification: $\times 200(\mathbf{c}, \mathbf{d}, \mathbf{f}, \mathbf{g}), \times 400(\mathbf{a}, \mathbf{b}, \mathbf{e})$. 

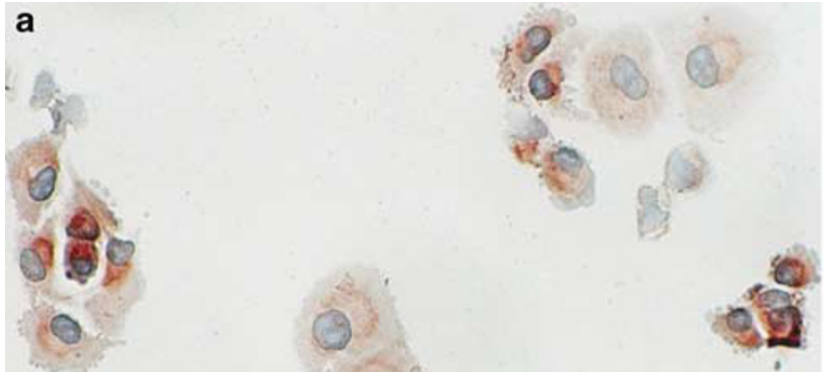

(9)

0

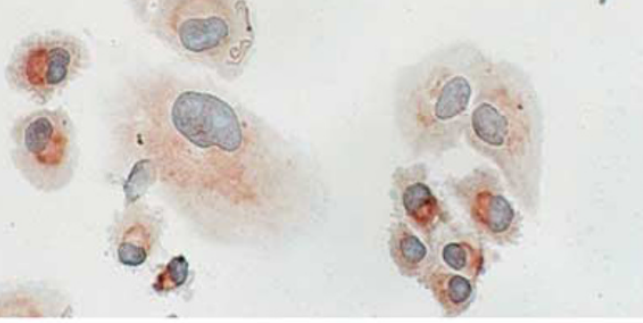

\section{c}
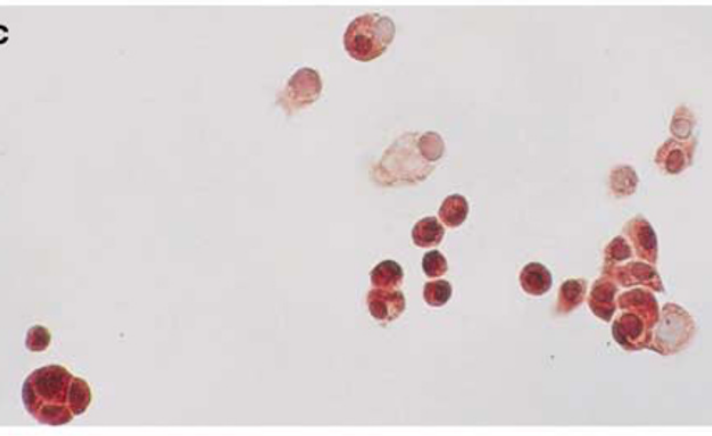

e

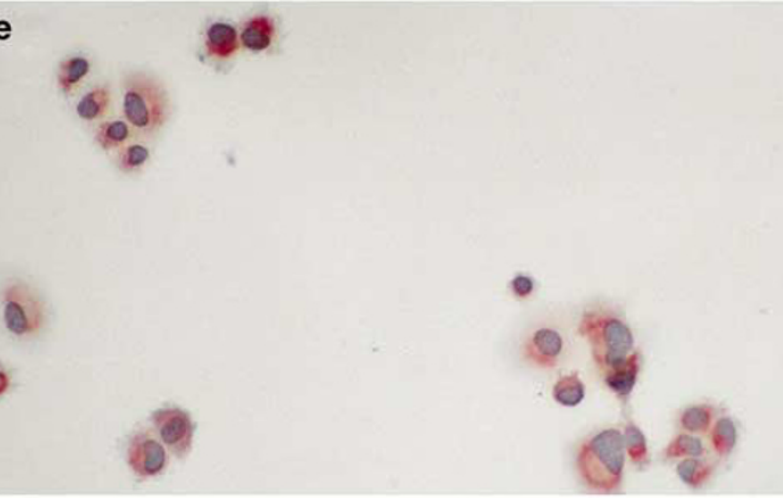

b
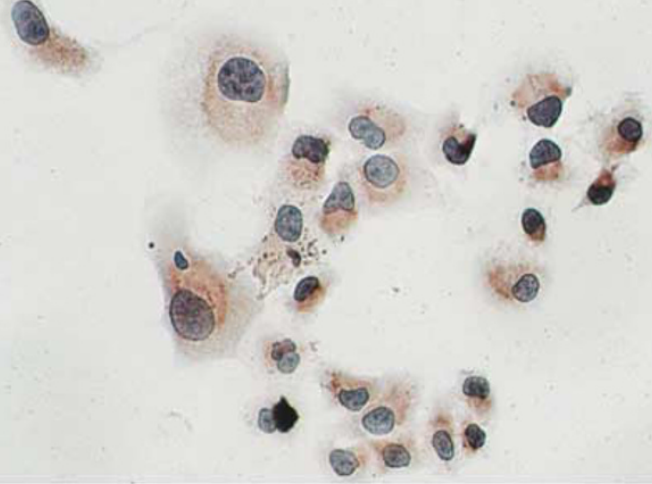

d
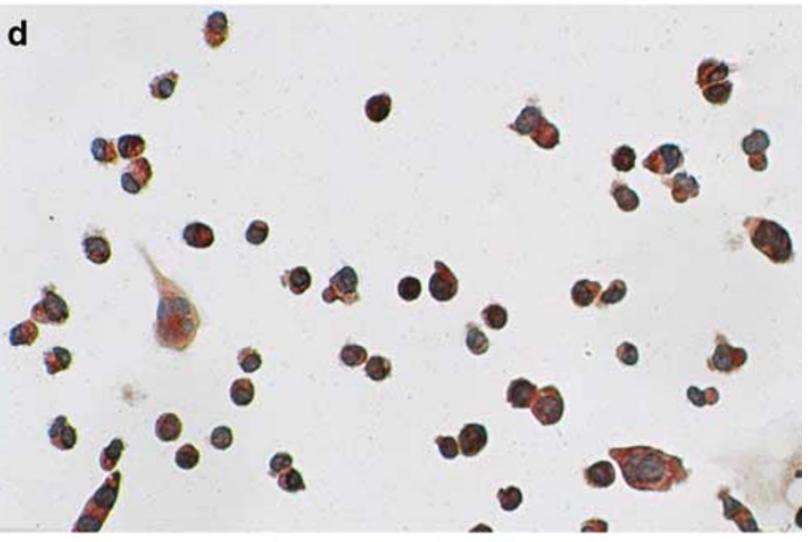

f

(2)

2.

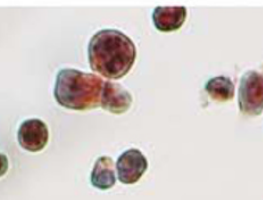

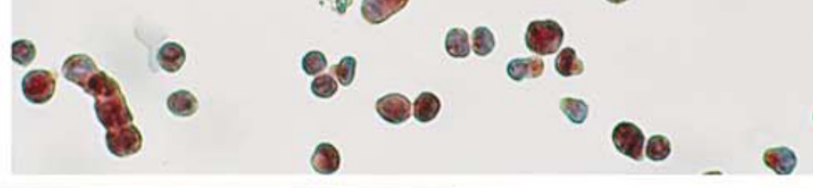

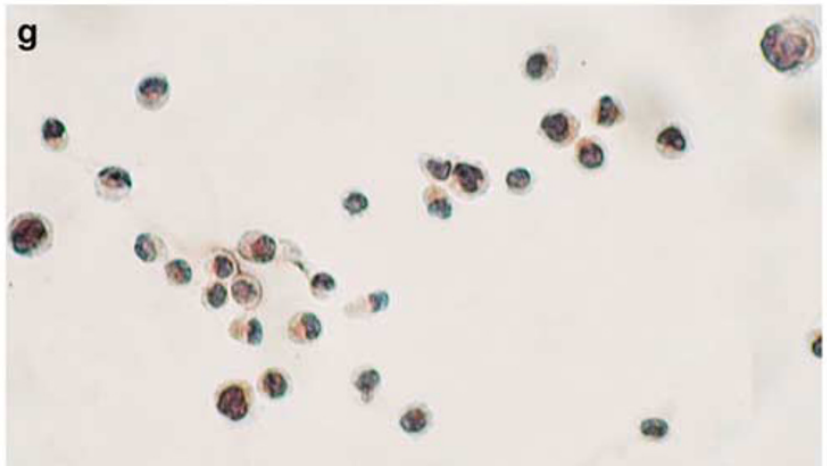


differentiated pancreatic adenocarcinomas, suggesting that it disappears from the most aggressive and dedifferentiated tumor cells. MMP-21 was not generally detected in neutrophils, like in esophageal SCCs, ${ }^{18}$ but was present occasionally in fibroblasts, in agreement with previous findings on certain skin disorders. ${ }^{19}$ MMP-21 expression diminished from T1 toward T4 and did not associate with the presence of metastatic lymph nodes or with alterations in CA19-9 values. This suggests that MMP-21 expression may be a marker of differentiation rather than invasiveness of pancreatic cancer, but this needs to be confirmed in a larger material of tumors.

Three pancreatic cancer cell lines were stimulated with cytokines relevant in the pathobiology of pancreatic cancer. TGF $\beta 1$ expression has been associated with better prognosis and lower grade tumors, while EGF and EGFR expression has been linked to poor survival and higher grade tumors. ${ }^{8}$ The expression of the $\mathrm{TNF} \alpha$ is upregulated in patients with pancreatic cancer and normalized after the pancreatic tumor is removed. ${ }^{39}$ All pancreatic cancer cell lines expressed low levels of MMP-21 basally independent on their differentiation status. EGF was the only cytokine that was consistently able to induce MMP-21 in the cell line with high metastatic ability, PANC-1, that has also been reported to produce MMP-2 and MMP-9. ${ }^{40-42}$ Unlike MMP-2 in PANC-1 cells, ${ }^{43}$ TGF $\beta 1$ did not upregulate MMP-21. MMP-21 mRNA was also expressed in the BxPC-3, a cell line with low metastatic potential shown to produce intermediate levels of MMP-2,44 and little MMP-9. ${ }^{41,44}$ Like MMP-21, AsPC-1 cells secrete MMP-7, which is regulated in these cells by EGFR-mediated MEK/ ERK signaling pathway. ${ }^{45}$

In several cancer types, MMP-26 has been shown to decrease progressively with loss of histological differentiation. ${ }^{24,46}$ However, in esophageal SCC, MMP-26 overexpression correlates strongly with depth of invasion, lymph node and distant metastases. ${ }^{47}$ In our material, MMP-26 was expressed by cancer cells in $52 \%$ of the adenocarcinomas examined. As seen with MMP-21, positivity was found in moderately differentiated but not in poorly differentiated cells. In immunopositive cancer cells, MMP-26 generally colocalized with TIMP-4. MMP-26 expression had a trend to increase from $\mathrm{T} 1$ to $\mathrm{T} 4$, and this protease was significantly more often expressed in tumors having metastatic lymph nodes. Furthermore, MMP-26 often colocalized with cells positive for laminin-5, an indicator of invasiveness of pancreatic tumor cells, ${ }^{48}$ thus linking this protease to aggressive behavior of pancreatic adenocarcinomas. However, a higher number of tumors would be required to definitely conclude whether MMP-26 could serve as a marker of metastasis in pancreatic cancer. MMP-26 can certainly influence the behavior of pancreatic cancer by activating MMP- $9,{ }^{49}$ an enzyme previously linked to invasiveness of this tumor.
Like in esophageal cancer cells, ${ }^{18}$ MMP-26 was not detected basally in three pancreatic cancer cell lines, and none of the cytokines tested were able to induce its expression at detectable levels. Estrogen has been suggested to modify the behavior of pancreatic cancer ${ }^{50}$ and would be a putative inducer of MMP-26 expression, as the promoter region of MMP-26 contains an estrogen-responsive element. ${ }^{46}$ Indeed, MMP-26 has been implicated as an important factor regulating the proteolytic activity in estrogen-dependent hyperplastic and malignant tissues. ${ }^{51}$ Furthermore, all studied pancreatic cancer cell lines have estrogen $\alpha$-receptors and all, but PANC-1 also estrogen $\beta$-receptors. ${ }^{52}$

This is the first study on TIMP-4 in pancreatic cancer: it was detected in cancer cells in $60 \%$ of pancreatic adenocarcinomas and decreased with cellular atypia. TIMP-4 was not observed in inflammatory or endothelial cells, but immunopositive fibroblasts were occasionally seen in agreement with results obtained in small cell lung cancer. ${ }^{53}$ TIMP-4 expression tended to diminish from $\mathrm{T} 1$ to $\mathrm{T} 4$ and its expression correlated with increased CA19-9 values. Unlike observed with other TIMPs in pancreatic cancer, ${ }^{5,55}$ the tendency of TIMP-4 downregulation related to aggressiveness was noted and found to agree with a recent report. ${ }^{56}$ Furthermore, TIMP-4 mRNA was least expressed in the most undifferentiated pancreatic cancer cell line PANC-1, while higher expression levels were detected in the less aggressive cell lines, AsPC-1 and BxPC-3.

TIMP-4 is a potent inhibitor of MMP-26. Steroid hormones influence TIMP-4 expression in breast ${ }^{57}$ and endometrial cancers. ${ }^{46}$ TIMP-4's expression was lower in malignant endometrial tumors than in normal or hyperplastic endometrium, ${ }^{46}$ in breast ductal carcinoma in situ compared to infiltrating ductal carcinoma, ${ }^{25}$ and in malignant chorioncarcinoma cells compared to normal cytotrophoblasts. On the contrary, TIMP-4 is upregulated in cervical cancer compared to corresponding normal tissue ${ }^{34}$ and in papillary renal cell cancer, ${ }^{58}$ as we observed in normal pancreatic tissue vs cancer.

In summary, our findings suggest that MMP-21 expression may be associated with pancreatic cancer differentiation and MMP-26 expression with metastasis. MMP-26 seems to be very tightly regulated in pancreatic cancer cells in vitro, while EGF, related to poor survival in pancreatic cancer, may induce MMP-21 in this tumor. Further studies in a larger sample set are warranted to elucidate the role of MMP-21 in tumor initiation and to investigate whether MMP-26 could serve as a serum marker for metastatic pancreatic cancer.

\section{Acknowledgements}

We thank Mrs Alli Tallqvist, Mrs Riitta Lehtinen, Ms Jonna Jantunen, and Ms Alexa Natori for skillful technical assistance, and Dr Päivi Holopainen for 
advice. This study was supported by grants from the Academy of Finland, Sigrid Jusélius Foundation, Cancer Foundation of Finland, Helsinki University Central Hospital Research Funds (EVO), Vetenskapsrådet, and Cancerfonden, Sweden, and personal grants to VB from Emil Aaltonen Foundation, Biomedicum Helsinki Foundation, Finnish Medical Society Duodecim, Finnish Cultural Foundation, Paulo Foundation, and University of Helsinki Funds, and a grant to TS from Edvard Welanders Stiftelse och Finsenstiftelsen, Sweden.

\section{Conflicts of interest}

None declared.

\section{References}

1 Gudjonsson B. Cancer of the pancreas: 50 years of surgery. Cancer 1987;60:2284-2303.

2 Ito H, Gardner-Thorpe J, Zinner MJ, et al. Inhibition of tyrosine kinase Src suppresses pancreatic cancer invasiveness. Surgery 2003;134:221-226.

3 Duffy JP, Eibl G, Reber HA, et al. Influence of hypoxia and neoangiogenesis on the growth of pancreatic cancer. Mol Cancer 2003;2:12.

4 Boyle P, Maisonneuve P, Mesquita BD. Cigarette smoking and pancreas cancer: a case control study of the search programme of the IARC. Int $J$ Cancer 1996;67:63-71.

5 Ekbom A, McLaughlin JK, Karlsson BM, et al. Pancreatitis and pancreatic cancer: a population-based study. J Natl Cancer Inst 1994;86:625-627.

6 Bansal P, Sonnenberg A. Pancreatitis is a risk factor for pancreatic cancer. Gastroenterology 1995;109:247-251.

7 Egeblad M, Werb Z. New functions for the matrix metalloproteinases in cancer progression. Nat Rev Cancer 2002;2:161-174.

8 Garcea G, Neal C, Pattenden C, et al. Molecular prognostic markers in pancreatic cancer: a systematic review. Eur J Cancer 2005;15:2213-2236.

9 Li YJ, Wei ZM, Meng YX, et al. Beta-catenin upregulates the expression of cyclin-D1, c-myc and MMP-7 in human pancreatic cancer: relationships with carcinogenesis and metastasis. World J Gastroenterol 2005;11:2117-2123.

10 Yamamoto H, Itoh F, Iku S, et al. Expression of matrix metalloproteinases and tissue inhibitors of metalloproteinases in human pancreatic adenocarcinomas; clinicopathologic and prognostic significance of matrilysin expression. J Clin Oncol 2001;19:1118-1127.

11 Yang X, Staren ED, Howard JM, et al. Invasiveness and MMP expression in pancreatic carcinoma. J Surg Res 2001;98:33-39.

12 Matsuyama Y, Takao S, Aikou T. Comparison of matrix metalloproteinase expression between primary tumors with or without liver metastasis in pancreatic and colorectal carcinomas. J Surg Oncol 2002;80:105-110.

13 Rigg AS, Lemoine NR. Adenoviral delivery of TIMP-1 and TIMP-2 can modify the invasive behavior of pancreatic cancer and can have a significant antitumor effect in vivo. Cancer Gene Ther 2001;8:869-878.

14 Bloomston $\mathrm{M}$, Shafii A, Zervos E, et al. TIMP-1 antisense gene transfection attenuates the invasive potential of pancreatic cancer cells in vitro and inhibits tumor growth in vivo. Am J Surg 2005;189: $675-679$

15 Evans JD, Stark A, Johnson CD, et al. A phase II trial of marimastat in advanced pancreatic cancer. Br J Cancer 2001;14:1665-1670.

16 Ahokas K, Lohi J, Lohi H, et al. Matrix metalloproteinase-21, the human orthologue for XMMP, is expressed during fetal development and in cancer. Gene 2002;301:31-41.

17 Ahokas K, Lohi J, Illman SA, et al. Matrix metalloproteinase-21 is expressed epithelially during development and in cancer and is upregulated by TGF-b1 in keratinocytes. Lab Invest 2003;83:1887-1899.

18 Ahokas K, Karjalainen-Lindsberg ML, Sihvo E, et al. Matrix metalloproteinases 21 and 26 are differentially expressed in esophageal squamous cell cancer. Tumour Biol 2006;27:133-141.

19 Skoog T, Ahokas K, Orsmark C, et al. MMP-21 is expressed by macrophages and fibroblasts in vivo and in culture. Exp Dermatol 2006;15:775-783.

20 Park H, Ni J, Gerkema FE, et al. Identification and characterization of human endometase (MMP-26) from endometrial tumor. J Biol Chem 2000;275: 20540-20544.

21 Ahokas K, Skoog T, Suomela S, et al. Matrilysin-2 (matrix metalloproteinase-26) is upregulated in keratinocytes during wound repair and early skin carcinogenesis. J Invest Dermatol 2005;124:849-856.

22 Bister VO, Salmela MT, Karjalainen-Lindsberg ML, et al. Differential expression of three matrix metalloproteinases, MMP-19, MMP-26, and MMP-28, in normal and inflamed intestine and colon cancer. Dig Dis Sci 2004;49:653-661.

23 Pilka R, Oborna I, Lichnovsky V, et al. Endometrial expression of the estrogen-sensitive genes MMP-26 and TIMP-4 is altered by a substitution protocol without down-regulation in IVF patients. Hum Reprod 2006;21:3146-3156.

24 Lee S, Desai KK, Iczkowski KA, et al. Coordinated peak expression of MMP-26 and TIMP-4 in preinvasive human prostate tumor. Cell Res 2006;16:750-758.

25 Zhao YG, Xiao AZ, Park HI, et al. Endometase/ matrilysin-2 in human breast ductal carcinoma in situ and its inhibition by tissue inhibitors of metalloproteinases-2 and -4: a putative role in the initiation of breast cancer invasion. Cancer Res 2004; 64:590-598.

26 Savinov AY, Remacle AG, Golubkov VS, et al. Matrix metalloproteinase 26 proteolysis of the $\mathrm{NH}_{2}$-terminal domain of the estrogen receptor beta correlates with the survival of breast cancer patients. Cancer Res 2006;66:2716-2724.

27 Ripley D, Tunuguntla R, Susi L, et al. Expression of matrix metalloproteinase-26 and tissue inhibitors of metalloproteinase-3 and -4 in normal ovary and ovarian carcinoma. Int J Gynecol Cancer 2006;16: 1794-1800.

28 Tunuguntla R, Ripley D, Sang QX, et al. Expression of matrix metalloproteinase-26 and tissue inhibitors of metalloproteinases TIMP-3 and -4 in benign endometrium and endometrial cancer. Gynecol Oncol 2003;89:453-459.

29 Salmela MT, Karjalainen-Lindsberg ML, Puolakkainen $\mathrm{P}$, et al. Upregulation and differential expression of matrilysin (MMP-7), metalloelastase (MMP-12) and tissue inhibitors of metalloproteinases- 1 and -3 in 
Barrett's esophageal adenocarcinoma. Br J Cancer 2001;85:382-392.

30 Ahonen M, Poukkula M, Baker AH, et al. Tissue inhibitor of metalloproteinases-3 induces apoptosis in melanoma cells by stabilization of death receptors. Oncogene 2003;22:2121-2134.

31 Greene J, Wang M, Liu YE, et al. Molecular cloning and characterization of human tissue inhibitor of metalloproteinases-4. J Biol Chem 1996;271:30375-30380.

32 Mannello F, Gazzanelli G. Tissue inhibitors of metalloproteinases and programmed cell death. Apoptosis 2001;6:479-482.

33 Radomski A, Jurasz P, Sanders EJ, et al. Identification, regulation and role of tissue inhibitor of metalloproteinases (TIMP-4) in human platelets. Br J Pharmacol 2002;137:1330-1338.

34 Lizarraga F, Espinosa M, Maldonado V, et al. Tissue inhibitor of metalloproteinases-4 is expressed in cervical cancer patients. Anticancer Res 2005;25: 623-627.

35 Pyke C, Salo S, Ralfkiaer E, et al. Laminin-5 is a marker of invading cancer cells in some human carcinomas and is co-expressed with the receptor for urokinase plaminogen activator in budding cancer cells in colon adenocarcinomas. Cancer Res 1995;55: 4132-4139.

36 Lieber M, Mazzetta J, Nelson-Rees W, et al. Establishment of a continuous tumor-cell line (panc-1) from a human carcinoma of the exocrine pancreas. Int J Cancer 1975;15:741-747.

37 Tan MH, Nowak NJ, Loor R, et al. Characterization of a new primary human pancreatic tumor line. Cancer Invest 1986;4:15-23.

38 Chen WH, Horoszewicz JS, Leong SS, et al. Human pancreatic adenocarcinoma: in vitro and in vivo morphology of a new tumor line established from ascites. In vitro 1982;18:24-34.

39 Ariapart P, Bergstedt-Lindqvist S, van Harmelen V, et al. Resection of pancreatic cancer normalizes the preoperative increase of tumor necrosis factor alpha gene expression. Pancreatology 2002;2:491-494.

40 Haq M, Shaeii AE, Zervos EE, et al. In vitro and in vivo matrix metalloproteinase production by pancreatic cancer cells and by distant organs. Int J Surg Investig 2000;1:459-465.

41 Takada M, Hirata K, Ajiki T, et al. Expression of receptor for advanced glycation end products (RAGE) and MMP-9 in human pancreatic cancer cells. Hepatogastroenterology 2004;51:928-930.

42 Schneiderhan W, Diaz F, Fundel M, et al. Pancreatic stellate cells are an important source of MMP-2 in human pancreatic cancer and accelerate tumor progression in a murine xenograft model and CAM assay. J Cell Sci 2007;120:512-519.

43 Ellenrieder V, Hendler SF, Ruhland C, et al. TGF-beta induced invasiveness of pancreatic cancer cells is mediated by matrix metalloproteinase- 2 and the urokinase plasminogen activator system. Int J Cancer 2001;93:204-211.

44 Ito H, Duxbury M, Zinner MJ, et al. Glucose transporter-1 gene expression is associated with pancreatic cancer invasiveness and MMP-2 activity. Surgery 2004; 136:548-556.

45 Tan X, Egami H, Ishikawa S, et al. Involvement of matrix metalloproteinase-7 in invasion-metastasis through induction of cell dissociation in pancreatic cancer. Int J Oncol 2005;26:1283-1289.

46 Pilka R, Norata GD, Domanski $\mathrm{H}$, et al. Matrix metalloproteinase-26 (matrilysin-2) expression is high in endometrial hyperplasia and decreases with loss of histological differentiation in endometrial cancer. Gynecol Oncol 2004;94:661-670.

47 Yamamoto $\mathrm{H}$, Vinitketkumnuen A, Adachi Y, et al. Association of matrilysin-2 (MMP-26) expression with tumor progression and activation of MMP-9 in esophageal squamous cell carcinoma. Carcinogenesis 2004;25:2353-2360.

48 Fukushima N, Sakamoto M, Hirohashi S. Expression of laminin-5-g-2 chain in intraductal papillary mucinous and invasive ductal tumors of the pancreas. Modern Pathol 2001;14:404-409.

49 Uria J, Lopez-Otin C. Matrilysin-2, a new matrix metalloproteinase expressed in human tumors and showing the minimal domain organization required for secretion, latency, and activity. Cancer Res 2000;60: 4745-4751.

50 Satake M, Sawai H, Go VL, et al. Estrogen receptors in pancreatic tumors. Pancreas 2006;33:119-127.

51 Li W, Savinov AY, Rozanov DV, et al. Matrix metalloproteinase-26 is associated with estrogen-dependent malignancies and targets alpha1-antitrypsin serpin. Cancer Res 2004;64:8657-8665.

52 Konduri S, Schwarz RE. Estrogen receptor beta/alpha ratio predicts response of pancreatic cancer cells to estrogens and phytoestrogens. J Surg Res 2007;140: 55-66.

53 Michael M, Babic B, Khokha R, et al. Expression and prognostic significance of metalloproteinases and their tissue inhibitors in patients with small-cell lung cancer. J Clin Oncol 1999;17:1802-1808.

54 Gress TM, Muller-Pillasch F, Lerch MM, et al. Expression and in situ localization of genes coding for extracellular matrix proteins and extracellular matrix degrading proteases in pancreatic cancer. Int J Cancer 1995;62:407-413.

55 Jones LE, Humphreys MJ, Campbell F, et al. Comprehensive analysis of matrix metalloproteinase and tissue inhibitor expression in pancreatic cancer: increased expression of matrix metalloproteinase-7 predicts poor survival. Clin Cancer Res 2004;15: 2832-2845.

56 Fernandez-Figueiras M-T, Puig L, Musulen E, et al. Expression profiles associated with aggressive behavior in Merkel cell carcinoma. Mod Pathol 2007;20:90-101.

57 Span PN, Lindberg RL, Manders P, et al. Tissue inhibitors of metalloproteinase expression in human breast cancer: TIMP-3 is associated with adjuvant endocrine therapy success. J Pathol 2004;202:395-402.

58 Hagemann T, Gunawan B, Schulz M, et al. mRNA expression of matrix metalloproteases and their inhibitors differs in subtypes of renal carcinomas. Eur J Cancer 2001;37:1839-1846. 